\title{
QGIS and Epigraphy: In Situ and Extra Situm Inscriptions ${ }^{\dagger}$
}

\section{Silvia Gazzoli}

check for

updates

Citation: Gazzoli, S. QGIS and Epigraphy: In Situ and Extra Situm Inscriptions. Environ. Sci. Proc. 2021, 10, 11. https://doi.org/10.3390/ environsciproc2021010011

Academic Editors: Sara Gonizzi Barsanti, Saverio Giulio Malatesta and Augusto Palombini

Published: 12 November 2021

Publisher's Note: MDPI stays neutral with regard to jurisdictional claims in published maps and institutional affiliations.

Copyright: (C) 2021 by the author. Licensee MDPI, Basel, Switzerland. This article is an open access article distributed under the terms and conditions of the Creative Commons Attribution (CC BY) license (https:// creativecommons.org/licenses/by/ $4.0 /)$.
Dottorato in Scienze del Patrimonio Letterario, Artistico e Ambientale, Università degli Studi di Milano, 20122 Milan, Italy; silviag.gazzoli@gmail.com

+ Presented at the ArcheoFOSS XIII Workshop-Open Software, Hardware, Processes, Data and Formats in Archaeological Research, Padova, Italy, 20-22 February 2019.

\begin{abstract}
The use of georeferenced relational databases for the localisation of epigraphic findings is widely attested with important examples. However, in order to propose an increasingly accurate representation of information related to inscriptions, some methodological issues need to be highlighted and, if possible, solved. This paper will address the problem of the place of discovery of the inscription, which could be in situ or extra situm.
\end{abstract}

Keywords: PostGIS; GIS; ODBMS; epigraphy

\section{Introduction}

In recent decades, the use of GIS software for the localisation of archaeological and epigraphic evidence has known a remarkable utilisation in archaeology, epigraphy, and, broadly, in Classics, widening methodological considerations on best practices [1,2]. For this reason, the addition of plug-ins and other implementations is becoming increasingly important, especially in the case of QGis [3], one of the most used open-source software, which otherwise would not allow the storage and retrieval of data organised in an objectrelational database. The possibility to connect topographical data and other information using the PostGIS [4] database extension allows the enhancement of relationships created in the PostgreSQL [5] environment with QGIS. Consequently, the cartographic localisation of findings using the <geo> element offers an extremely interesting perspective that could, and should, be deepened. The combination of these two tools, which appears to be fundamental for a correct topographical contextualisation of ancient evidence, has, however, brought to light few methodological criticalities regarding inscriptions.

The aim of this paper is to highlight one of these methodological issues and to propose solutions that could be used in databases and digital archives.

\section{Material and Methods}

The projects consisted of the creation of a catalogue collecting several hundred funerary inscriptions regarding children and [6,7] belonging to a well-defined topographical context (Cisalpina) and referring to a wide chronological period between the so-called cultural 'romanisation', and the fall of the Western Roman Empire. The main aim was to highlight information regarding infant mortality in these territories focusing on families and, broadly, on the socio-economic landscape. This catalogue led to the creation of a database in order to archive, manage and organise epigraphical texts and create connections between archaeological excavations mapped in the GIS and the place of discovery of inscriptions. During the design stage of the database, some methodological issues arose, related to the inscriptions' place of discovery.

As many scholars highlighted in manuals (for example [8]), epigraphic lines of evidence could be divided into different groups regarding the place of discovery. The first (1) could identify inscriptions found in situ, such as during archaeological excavations, while the second (2) includes all documents found extra situm, so re-used (for example in buildings' walls or in defensive systems such as towers) or part of collections. In all 
these possible and attested cases, information regarding the place of discovery is usually very vague or missing. The third group (3) consists of inscriptions only mentioned in manuscripts.

The importance of the context is fundamental considering the inscription's value in the community [9-11]. These documents could also be defined as monumenta memoriae [12]: consequently, the epitaph served as a tangible memory of the deceased for his or her familia but also for the community itself.

Numerous inscriptions catalogued in this project [6,7], in fact, have been found in periods prior to the introduction in Italy of the modern excavation techniques, and, above all, in the stage prior to the use of geo-referencing tools. For this reason, the only indications of provenance often derive from manuscripts, whose tradition merged into the 'Corpus Inscriptionum Latinarum'. In these cases, the place of discovery is indicated by reference to the ownership of the land, the nearest famous monument, or the road layout of the time. Only for inscriptions found since the second half of the nineteenth century is it possible to refer to more precise documentation owing to the increasing circulation of archaeological bulletins such as the Notizie degli Scavi di Antichità [13]. However, the criticality brought by collecting, which had an important role in moving archaeological finds from the place of discovery to the villas of the most important family, remains until contemporary times. In the catalogue there are very few inscriptions whose place of discovery has been recorded using georeferencing system or have been reported in excavation plants (Appendix A). It does not seem appropriate, in order to propose scientifically and historically correct queries, to limit the geographic information to the name of the city (ancient or modern), also due to the characteristic toponymy of this area with several similarities.

\section{Conclusions}

The site of discovery represents important information, if not fundamental, for the reconstruction of the historical and social landscape of a territory. In most cases, however, with the information at our disposal, the result could not be scientific acceptable or could become misleading. For this reason, for this project's database, it was decided to highlight the issue by deepening the different options mentioned by the sources regarding all catalogued findings. Therefore, a new field was inserted in the main table concerning inscriptions in which the degree of accuracy is explained on a scale of four possibilities: 0-not determined, 1-scarce, 2-possible, and 3-optimal. This last option is suitable only in the few cases in which the inscription has been found during archaeological excavations mapped in modern Archaeological plans (Appendix A).

During the design stage, two additional tables, called 'Riutilizzo (re-use)' and 'Collezioni (collections)' were included to store as accurately as possible information regarding the building where inscriptions or collections were placed. Data related to the finding sites, therefore, can be inserted in a text field that does not provide the NULL value to avoid compilation or query errors. This field is related to the previously mentioned tables. Thus, only inscriptions within the range of 2-3 in the field concerning topographical accuracy could be used in geographical studies.

In conclusion, the aim to propose a georeferenced archiving tool based on the ER model highlighted some methodological criticalities deriving from information related to inscriptions' sites. The identified solution, within minimal changes to the initially hypothesised DB structure, facilitated the data entry step but also the retrieval of information on a geographical basis.

Data Availability Statement: This database was part of a PhD project.

Conflicts of Interest: The author declares no conflict of interest.

\section{Appendix A}

The following cases serve as examples of the issue related to the provenance of the inscriptions and the approach proposed: 
- CIL V, 5374 (=EDR165009) is a cinerarium from Comum; previously, it was part of the Giovio Collection and is now stored in a local archaeological museum. In the Corpus are mentioned only references to tradition regarding its provenance from the Roman city (Comi). In this case, in the field related to the accuracy of provenance, the number is 1 , as the area is vaguely defined and the production of the artifact is typical of this territory.

- $\quad$ AE 2005, 645 (=EDR178812) is a stela in local stone regarding a young deceased person and his mother. The monument was found during an archaeological excavation in the city of Comum related to a tomb. In this case, the accuracy of information provided can be synthesised with number 3 (as maximum).

\section{References}

1. D'Andria, F.; Semeraro, G. Un Sistema integrato per la gestione della cartografia e dei dati di scavo. Archeol. Calc. 1993, 4, 159-180.

2. Semeraro, G. Informatica ed elaborazione dei dati archeologici. Archeol. Calc. 1996, 7, $259-268$.

3. QGIS. Un Sistema di Informazione Geografica Libero e Open Source. Available online: qgis.org (accessed on 30 March 2021).

4. PostGIS. Spatial and Geographic Objects for PostgreSQL. Available online: postgis.net (accessed on 30 March 2021).

5. PostgreSQL. Available online: postgresql.org (accessed on 30 March 2021).

6. Gazzoli, S. QGis, database ed epigrafia: Un Progetto in corso. Archeol. Calc. 2019, 30, 519-522.

7. Gazzoli, S. The use of relational databases in epigraphy: A case study. Stud. UBB Digit. 2018, 63, 19-30. [CrossRef]

8. Di Stefano Manzella, I. Mestiere di Epigrafista. Guida alla Schedatura del Materiale Epigrafico Lapideo (Vetera, 1); Edizioni Quasar: Roma, Italy, 1987.

9. Susini, G.C. Le scritture esposte. In Lo Spazio Letterario di Roma Antica, 2, La Circolazione del Testo; Salerno Editrice: Roma, Italy; Salerno, Italy, 1989; pp. 271-305.

10. Sartori, A. Le forme della comunicazione epigrafica. In Monumenti Sepolcrali Romani in Aquileia e Nella Cisalpina. XXVI Settimana di Studi Aquileiesi 1995 (=AADD 43); Editreg Editore: Trieste, Italy, 1997; pp. 39-65.

11. Sartori, A. La comunicazione epigrafica e l'epigrafia comunicata. SEBarc 2009, 7, 63-73.

12. Iglesias Gil, J.M.; Ruiz-Gutierrez, A. (Eds.) Monumenta et Memoria: Estudios de Epigrafía Romana; Edizioni Quasar: Roma, Italy, 2017.

13. Notizie degli scavi di antichità: Comunicate alla R. Accademia dei Licei per Ordine di S.E.; Il ministro Della Pubblica Istruzione: Roma, Italy, 1876. 